\title{
THE IMPROVEMENT OF THE STUDENTS' SPEAKING SKILL OF BALI WIDYA KUSUMA HOTEL SCHOOL THROUGH THREE- STEP INTERVIEW
}

\author{
Ida Ayu Made Sri Widiastuti \\ English Education Study Program \\ Faculty of Teacher Training and Education \\ Mahasaraswati Denpasar University
}

\begin{abstract}
This present study was a classroom action research which was conducted to overcome the students' problem in mastering speaking skill by implementing Three- Step Interview. The subject of this study was the first semester students of Bali Widya Kusuma Hotel School. There were two cycles in which every cycle consisted of two sessions. The research was started by administering the initial reflection. In accordance to the main objective of this study, the initial reflection was intended to establish the real pre existing speaking skill mastery of the subjects under study in English. Based on the result of the pre-test which was carried out in the pre-cycle, showed that the subjects' skill in speaking was categorized as insufficient, which was 54.48. From the technique implemented, there was significant improvement from the subjects' skill in speaking, in which it improved from insufficient to good, which was 68.09 in cycle I and 76,29 in cycle II. This research furthermore showed there was changing learning behavior as the result of the positive responses concerning the technique applied in improving the subjects' speaking skill. To sum up, the present clasroom action study proved that the implementation of three-step interview could improve speaking skill in the first semester students of Bali Widya Kusuma Hotel School.
\end{abstract}

Key words: Implementation, Three- Step Interview, Speaking Skill

\begin{abstract}
ABSTRAK
Penelitian ini bertujuan untuk mengetahui efektifitas pelaksanaan Three Step Interview dalam meningkatkan keterampilan berbicara mahasiswa semester pertama Bali Widya Kusuma Hotel School. Subjek penelitian ini adalah mahasiswa semester pertama Bali Widya Kusuma Hotel School. Penelitian ini adalah penelitian tindakan kelas yang dilakukan untuk mengatasi masalah mahasiswa dalam menguasai keterampilan berbicara. Terdapat dua siklus di mana setiap siklus terdiri dari dua sesi. Penelitian tindakan kelas ini dimulai dengan pemberian refleksi awal. Sejalan dengan tujuan utama dari penelitian tindakan kelas, refleksi awal dimaksudkan untuk mengetahui kemampuan berbicara mahasiswa subyek yang diteliti dalam bahasa Inggris secara jelas. Berdasarkan hasil prates, yang dilaksanakan pada pra siklus, menunjukkan bahwa kemampuan siswa dalam berbicara dikategorikan kurang yaitu 54.48. Selanjutnya penelitian
\end{abstract}


tindakan kelas dilakukan dengan pelaksanaan three step interview dalam rencana dua siklus. Berdasarkan teknik yang dilaksanakan, terdapat peningkatan yang signifikan pada kemampuan berbicara mahasiswa, dimana hal tersebut meningkat dari kurang menjadi baik, yaitu 75.74 pada siklus I dan 79.48 pada siklus II. Penelitian ini selanjutnya menunjukkan adanya perubahan perilaku belajar yang positif sebagai hasil dari teknik yang diterapkan dalam meningkatkan keterampilan berbicara subyek. Singkatnya, penelitian tindakan kelas ini membuktikan bahwa pelaksanaan Three Step Interview dapat meningkatkan keterampilan berbicara pada mahasiswa semester pertama Bali Widya Kusuma Hotel School.

Kata kunci: Implementasi, Three Step Interview, Keterampilan Berbicara

\section{Background of the Study}

Speaking is considered as one of the four language skills that has an important role in language point of view. Speaking skill means the ability to express about the feeling to make a good communication orally to others in the communities. The main purpose of studying speaking in English as a foreign language is to help the learners to be able to use the target language. This can be gained if the students can speak during the teaching learning process.

In relation to the importance of speaking skill in teaching English, there were many problems that the first semester students of BWK hotel school face in learning English as their foreign language especially in speaking. The problems are students often inhibited about trying to say things in foreign language in the classroom, worried about making mistakes fear fuller critics or losing face, or simply shy of the attention that their speech attracts. Second problem is because of the lack of motivation to practice the English as a foreign language in daily conversation and they have no idea to express themselves in speaking. They also feel afraid and ashamed to take part in the conversation. Last problem is, most of English teacher are not be able to use an appropriate teaching strategy to teach English in their classroom.

Many factors can cause the problem of the students' speaking skills namely the students' interest, the material, and the media among others including the technique in teaching English. That is why the appropriate technique in delivering the lesson in the classroom should be considered, which 
is able to cover all the above problems. Based on the reason above, teacher should not only concern on the linguistics ability of the students but also on their communicative ability. That is why the teachers have challenge to enable their students to master English well, especially speaking English in class or out of the class. In order to develop the learners' communicative ability, the teacher needs to create a scenario to teach the target language in an active and interesting manner. Teachers also help students adapt their speeches and informal talks so as to correspond to the intended audience, the information to be communicated, and the circumstances of the occasion at which they will speak. The teachers can illustrate how well-known speakers have adapted their presentations in ways to suit these different circumstances. Teachers can enable learners to present ideas to individual peers, peer groups and entire classes of students. They can learn to speak on a subject of their own choosing or on teacher assigned topics.

Many techniques can be applied; one of them is Three- Step Interview. Three- Step Interview is a cooperative structure in which members of a team interview one another on a particular topic. The purpose of teaching Three - Step Interview is to generate opportunities for the students to become more active in learning in the class activities or in their environment and to gather students in a conversation for analysis purpose and new information. In this case the study of group discussion and whole class discussion activities, therefore the students would have much deeper understanding in their speaking activities. Group of discussion and whole class discussion is an extremely attractive technique in number of reason: the students' talking time is increased, it gives the students opportunities to use the language to communicate which each other, and students will have experience both teaching and learning in the group. It can also reduce the boredom during the process since it allows the students to actively practice their language in the classroom activities.

Based on the background above, the Three- Step Interview technique is believed to motivate and measure the students' ability in speaking skill. 


\section{RESEARCH METHOD}

This study aimed at improving the ability of the first semester students of Bali Widya Kusuma (BWK) Hotel School in speaking skill through threestep interview. It followed a classroom action research as the research design in this study.The study started by administering the initial reflection or pre- test (IR) which was intended to evaluate the pre- existing speaking skill of the subjects while reflection or posttest $(\mathrm{R})$ meant to reveal the expected increase in the subjects' speaking achievement after the subjects have been taught communicative skill through Three- Step Interview.

In this classroom action study, the activities of teaching and learning process were divided into two cycles where each cycle consisted of two sessions. Each session consisted of four interconnected activities, namely: planning $(\mathrm{P})$, action $(\mathrm{A})$, observation $(\mathrm{O})$, and reflection $(\mathrm{R})$.

Planning was done to determine what to do in the action and the instruments used for collecting data. Before giving the treatment, the researcher had to prepare instructional planning for all the sessions. Planning here referred to the step of the action and instruments required in collecting the data needed.

Action was the implementation of the previous planning. This was the main activity in the classroom action study. Actions referred to what the researcher really did in the classroom setting during the teaching processes. What the researcher did successively in every classroom session was principally based on a teaching technique, namely pre-activities, whilst-activities and post-activities.

Observation was the activity of observing the classroom situation during the action, including the response of the students toward the implementation of the technique that was being applied. Here, the collaborator took notes on everything happened in the classroom. In this classroom action study the researcher acted or behaved as a classroom teacher as well as an observer. This suggested that classroom observation was simultaneously carried out. It also provided the basic reflection for the present cycle. In other hand, to observe subjects' feeling, it was done in the end of the last cycle by administering questionnaire. The result of the questionnaire was observed to know 
the effectiveness of the technique that had been used, whether students like or not.

Reflection was the activity of reflecting and analyzing the action as it was recorded or based on the results of the observation. It was given to the subjects being studied on the basis of teaching process. Reflection was used to diagnose the cause of the unsuccessful actions given. From the classroom observation activities and the notes taken by the collaborator to get feedback on what had been done. It is done in the end of the cycle in order to identify the strengths and weaknesses of the action. The strength of the action in the first cycle would be keep doing in the next cycle. While, if problem was found in the first cycle, then researcher would do some revision of all that had been planned including lesson plan, instrument, and also the teaching media.

Research instrument is the tool used to collect data needed during the study. It will help researcher to get valid and also reliable data. Without the instrument, researcher can do nothing. Selecting a valid and reliable research instrument was a very essential step of scientific investigation. This was due to the fact that merely the qualified research instruments on their own could result in the valid and reliable required data of the study being carried out. Without instruments, it was impossible for the researcher or observer to collect the needed data which is used to determine its validity. In relation with what has been stated above, there were two research instruments that are used in collecting data in this study. They were test consist of pre-test and post-test and questionnaire.

\section{FINDINGS AND DISCUSSION}

\section{Findings}

There were three kinds of instruments used to gather the data of present classroom action research, there were pre- test, post- test (in cycle I and cycle II) and questionnaire. The researcher made up the research into two cycles to find a very significant improvement on the students' ability on speaking skill through Three- Step Interview. The pre- test in speaking was administrated to the subjects under study to collect their pre- existing ability in speaking skill. In pre-test the subjects were asked to interview their classmate. Furthermore, Post- test was 
administered at the end of each cycle. This was due to the fact that each cycle was ended with the administration of reflection.

\section{Pre-Cycle}

Initial reflection or pre- test was administered to the subjects under the study in order to obtain the students' pre-existing speaking skill. The pretest was conducted by asking the students to answer the questions orally in order to determine their ability in speaking.

The tabulation of data showed that the mean score of the pre-test in this present classroom present study pointed out figure of 54.48. From the results of tests the researcher knew that the students 'ability in speaking were low. The result of pre- test indicated that the students had some problems in speaking skill. The researcher then conducted cycle I to solve the students' problem in speaking skill. Based on the result of the students' pre-test, the researcher proposes alternative teaching strategy by using Three-Step Interview.

\section{Cycle I}

The result of the score in the first cycle were collected through post test on session two, which was after the student received treatment how to improve speaking through Three-Step Interview.

The mean score for cycle I was 75.74 with the predicate is sufficient. Based on these data, the percentage of students who achieved the minimum passing grade score in the first cycle was equal to $50.45 \%$. In accordance with the success indicators that mentioned in section III that the action research cycle can be terminated if at least $80 \%$ of students have achieved $\mathrm{PG}$, then the cycle will continue to the second cycle.

\section{Cycle II}

The result of the score in the second cycle were collected through post test on session four, which was after the student received treatment how to improve speaking through Three-Step Interview. The topic in this cycle was about agreeing and disagrees.

The mean score for cycle II was 79.48 with the predicate is good. Based on these data, the percentage of 
students mastery in the second cycle was equal to $85.36 \%$. In accordance with the success indicators that mentioned in section III that the action research cycle can be terminated if at least $80 \%$ of students have achieved PG, then this action research would be stop on the second cycle.

Table 1. The mean score of Pre Test, Post Test I, and Post Test II

\begin{tabular}{|c|c|c|c|}
\hline \multirow{2}{*}{\multicolumn{2}{|c|}{ Pre-Test }} & & \\
\hline & & Test I & Test II \\
\hline Mean & 54.48 & 75.74 & 79.48 \\
\hline
\end{tabular}

To make it clear, the findings of the present classroom action study, that was the rising comparative mean figures of the pre-test scores, the posttest scores in cycle I and cycle II could be graphically as follows:

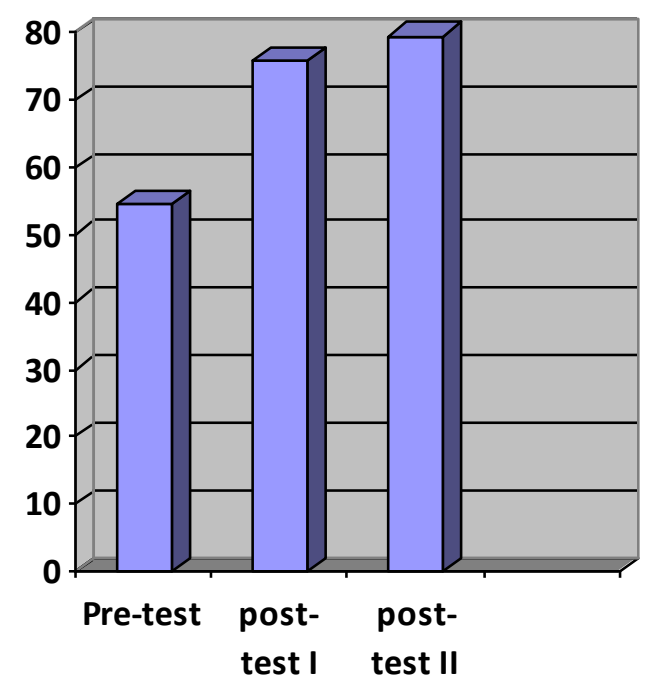

Graphic 1. Depiciting the subject's progressing grand mean taught in speaking from pre test and post test through Three Step Interview

To make this finding more significant, therefore the additional data required for the present class action study were collected through administering questionnaires to all the students at the end of cycle 2 . The answers of the questionnaires were quantitatively scored using the rating scale $0-3$ (Score of option $\mathrm{A}=3, \mathrm{~B}=$ 2, $\mathrm{C}=1$, and $\mathrm{D}=0$ ). The scores gathered from administering questionnaires showed the subjects' changing attitude and motivation in speaking skill through Three- Step Interview. The result of the analysis of questionnaire showed the comparative percentage of $76 \%, 20 \%, 4 \%$ and $0 \%$ for the respective total responses of the item of questionnaire showing $\mathrm{A}, \mathrm{B}, \mathrm{C}$, D. The comparative percentages of the items of questionnaire showed the $\square$ sctydents' positive changing attitudes and motivation in speaking skill proved the implementation of Three-Step Interview. 


\section{DISCUSSION}

The data analysis above which determined the findings of the present study presented that the mean score of the IR or pre-test score (Xo) was still weak in category. This mean figure obviously showed that the ability of the subjects under study was relatively low in speaking skill.

The mean score of IR or pretest (X0) was obtained by the subject under study in speaking skill pointed out the mean figure 54.48 . This mean figure clearly showed that the preexisting speaking skill of the students was low. The mean figure of the reflection in cycle I was obtained by subjects under study was automatically higher than the mean figure of the IR. The result of mean figure in cycle I was 75.74. This mean figure revealed higher than the mean figure of the IR. This grand mean figure revealed that teaching speaking skill to the first semester students of Bali Widya Kusuma Hotel School could be significantly improved.

The result of the data analysis of the reflection was obtained by the subjects in cycle II turned out to show the progressing mean figure 79.23 Compared with the mean figure of IR, the mean figure was obtained by the subject under study in each cycle was convincingly higher than IR. There was the difference mean figure of 54.74 (75.74 - 79.48) between the mean of cycle I and Cycle II. This mean figure suggested that teaching speaking in cycle II through Three- Step Interview could be remarked to be more effective than cycle I. This was due to the fact that the cycle II was a revised version of cycle I; therefore, the teaching scenario in cycle II was accordingly revised by taking into account the weaknesses found out in cycle I. It showed that the mean score of the reflection in cycle II was higher than cycle I.

Moreover, the comparative percentages scores of the total response of the questionnaires for items $\mathrm{A}, \mathrm{B}, \mathrm{C}$ and D were $76 \%, 20 \%, 4 \%$ and $0 \%$. This score established that the students' changing learning behaviors, attitude, and motivation had progressed positively. In addition, it was also suggested that improving speaking skill through the Three-Step Interview could create an active and conducive classroom activity. As the result, the students' motivations as well as their 
ability in speaking skill were impressively improved.

The study was aimed at improving speaking skill through Three- Step Interview. This aim was successfully achieved after two cycles were carried out. The students involved in to speak more by using Three-Step Interview.

\section{CONCLUSION}

At the end of all process of the final project of this study, some conclusions were described based on the results of the data analysis. The main data required for the present classroom action study were gathered through administering IR and reflection or post- test under study. Some supplementary data were collected by means of administering questionnaires by the end of cycle I. based on the students' problem in speaking skill, because they still have poor ability such as in vocabulary, pronunciation, fluency and comprehension. All of them also were confused in expressing their idea orally.

Based on the problems the researcher used Three- Step Interview technique to solve the problem in this study. It can be seen in the comparing average score of pre- test, cycle I and cycle II which was the average score of pre- test was 54.48 mean score and improved to 75.74 in cycle $\mathrm{I}$, and improved again to 79.48 mean score in cycle II.

The questionnaire also became a successful record of the technique. It was clearly seen that the students posted positive response toward the implementation of Three- Step Interview. The additional data from questionnaire showed that $76 \%$ subjects very liked Three- Step Interview, 20\% subjects liked ThreeStep Interview, 4\% subjects quite like Three- Step Interview and 0\% subjects did not like this technique.

The application of Three- Step Interview could improve the students' achievement in speaking skill; it showed the students' personal improvement. They could share their opinions with their group and they were more motivated in speaking skill.

\section{REFERENCES}

Brown, H. D. 2004. Language Assessment: Principles and Classroom Practice. New York: Pearson Education Inc.

Brown, H. D. 2007. Principles of Language Learning and Teaching. England: Longman. 
Cohen, L., Manion, L., and Morrison,

K. 2000. Research Method in

Education $5^{\text {th }}$ Edition. London:

Routledge Falmer.

Harmer, J. 2004. Just Listening and Speaking. London: Marshall Cavendish ELT.

Harmer, J. 2007. The Practice of English Language Teaching. Cambridge: Pearson Longman.

Macpherson, A. 2007. Cooperative Learning Group Activities. Canada: Kwantlen University College. 